\title{
Model Calibration of Prefabricated Timber Wall Frames Made of Hieronyma Alchorneoides and Gmelina Arborea Timber Using Nail and Screw Fasteners
}

\section{Kalibracija modela montažnih drvenih zidnih okvira izrađenih od drva Hieronyma alchorneoides i Gmelina arborea uz pomoć čavala i vijaka}

\author{
Original scientific paper • Izvorni znanstveni rad \\ Received-prispjelo: 3. 4. 2017. \\ Accepted-prihvaćeno: 21. 2. 2018. \\ UDK: $630 * 824.21 ; 630 * 824.23 ; 630 * 833.01$; \\ doi:10.5552/drind.2018.1722
}

\begin{abstract}
The object of this research is to develop a model for the calibration of prefabricated timber wall frames (PTWFs) with dimension of 244 by $244 \mathrm{~cm}$ (width by height) respectively made of Gmelina arborea Roxb. and Hieronyma alchorneoides Allemão wood and two types of fastener (nails and screws). The PTWFs were submitted to a lateral load test and the vertical and horizontal displacement, maximum load $\left(P_{m}\right)$, strength, stiffness values and mode of failure were determined. Results showed a greater failure percentage in the joint between the central stud and the top and bottom plates for both species and both fastener types used. PTWFs made of $\underline{H}$. alchorneoides timber using screws showed greater values than PTWFs made of G. arborea for load at the proportionality limit and maximum load. Finally, computational model showed that the highest calibration percentage was achieved in the vertical orientation in PTWFs made using nails in both species. Meanwhile, PTWFs using screws showed calibration percentages of 58.0 and $43.5 \%$. The highest calibration percentage of $89.9 \%$ was recorded in G. arborea PTWFs joined with nails, whereas the lowest calibration percentage of $69.4 \%$ was recorded in $\underline{H}$. alchorneoides $P T W F$ soined with screws.
\end{abstract}

Keywords: structural timber, vertical diaphragms, lateral loads, light frame, fastener, calibration model

SAŽETAK • Cilj istraživanja bio je razviti model za kalibraciju montažnih drvenih zidnih okvira (PTWF) dimenzija $244 \times 244 \mathrm{~cm}($ širina $\times$ visina) izrađenih od drva Gmelina arborea Roxb. i Hieronyma alchorneoides Allemão te uz upotrebu dviju vrsta vezivnih elemenata (čavala i vijaka). PTWF-ovi su podvrgnuti testu bočnog opterećenja

\footnotetext{
Authors are Bachelor of Science, $\mathrm{PhD}$ and Bachelor of Science at Instituto Tecnologico de Costa Rica, Escuela de Ingeniería Forestal, Cartago, Costa Rica; ${ }^{2}$ Authors is Bachelor of construction, Bachelor of construction at Instituto Tecnologico de Costa Rica, Escuela de Ingeniería Construction, Cartago, Costa Rica

Autori su prvostupnik, doktor znanosti i prvostupnik Tehnološkog instituta Costa Rica, Šumarski fakultet, Cartago, Costa Rica.

${ }^{2}$ Autor je prvostupnik, građevinarstva Tehnološkog instituta Costa Rica, Građevinski fakultet, Cartago, Costa Rica.
} 
te su utvrđeni vertikalni $i$ horizontalni pomak, maksimalno opterećenje $\left(P_{m}\right)$, čvrstoća, krutost $i$ način oštećenja. Rezultati su pokazali najveći postotak oštećenja u spoju između središnjeg nosača i gornjega odnosno donjeg okvira za PTWF-ove od obiju vrsta drva i spojenih obama tipovima vezivnih elemenata. PTWF-ovi izrađeni od drva $\underline{H}$. alchorneoides $i$ spojeni vijcima imali su veće vrijednosti opterećenja na granici proporcionalnosti $i$ maksimalnog opterećenja od PTWF-ova proizvedenih od drva G. arborea. Konačno, računalni je model pokazao da je najveći postotak kalibracije postignut u vertikalnom smjeru u PTWF-ova izrađenih od obiju vrsta drva i spojenih čavlima. Istodobno, PTWF-ovi spojeni vijcima pokazali su postotke kalibracije 58,0 i 43,5\%. Najveći postotak kalibracije bio je 89,9\%, a zabilježen je u PTWF-u od drva G. arborea i spojenom čavlima, dok je najniži postotak kalibracije ustanovljen u PTWF-u od drva $\underline{H}$. alchorneoides spojenom vijcima, a iznosio je 69,4\%.

Ključne riječi: građevno drvo, vertikalne membrane, bočna opterećenja, svjetlosni okvir, vezni elementi, model kalibracije

\section{INTRODUCTION 1. UVOD}

Wood was among the first materials used by humans for construction (Rathod, 2015). However, to date the use of structural timber has decreased due to the arrival of new construction materials (Sheikh and Ahmad, 2015; Demirkir et al., 2013). In Costa Rica, a small country of Latin America, the main consumer of sawn wood is the construction sector (Serrano and Moya, 2011). However, the construction sector has experienced an accelerated process of change toward metallic, plastic and concrete materials (Serrano and Moya, 2011).

Furthermore, a great variety of species has been planted as part of the reforestation activities in Costa Rica, resulting in an important contribution to the lumber market (Tuk, 2010; Moya et al., 2015; Tenorio et al., 2016). Mechanical properties of G. arborea lumber are among the most extensively studied in Costa Rica and their great potential has been demonstrated for uses such as structural components (Tenorio et al. 2016), in lumber, and other specific uses (Tenorio et al., 2011; Tenorio, 2012). Regarding H. alchorneoides lumber, Tenorio et al. (2016) noted that this species might have a potential for structural applications due to its mechanical properties. However, among the noted disadvantages of the use of plantation timbers in construction, is that only recently the allowable design stress data for plantation species has became available (Moya and González, 2013; Tenorio et al., 2016).

It is important to mention that timber structures allow proper habitability under adequate stress of the structural elements (Bongers et al., 2013). In order to guarantee optimal structural behavior of a structure, nonetheless, research must be done on different properties of wood as well as on joints between wooden elements, as these represent the weak spot of timber structures (Prevatt et al., 2014). This opens the trail for the development of studies on framing structures (Tenorio et al., 2011). A series of structural aspects of the wall can be observed from the action of the forces present in it, such as the behavior of displacement in relation to forces applied, strength, stiffness values and the mode of failure of the joint (Zheng et al., 2015).

On the other hand, timber structures are extensively used in the United States as residential houses, schools, and office buildings. Timber diaphragms (walls, floors, and ceilings), which provide lateral stability, are important components of these buildings. They consist of framing (studs, joists, and blocking), sheathing (timber structural panels), and fasteners (nails, screws, or staples), which connect the sheathing to the framing (Demirkir et al., 2013). However, wood construction has not been widely used especially in developing countries (Sawata et al., 2013), such as Costa Rica.

Despite all information on timber wall frame behavior under lateral loads available for species from other regions of the world, there is a lack of knowledge on the structural properties of wall frames made of tropical timber species for framing constructions. In face of this situation, the object of this research is to develop a model for the calibration of prefabricated timber wall frames (PTWFs) with dimension of 244 by $244 \mathrm{~cm}$ (width x height) made of Gmelina arborea Roxb. and Hieronyma alchorneoides Allemão timbers using two types of fastener (nails and screws).

\section{MATERIALS AND METHODS} 2. MATERIJALI I METODE

\section{Timber used}

Gmelina arborea Roxb. and Hieronyma alchorneoides Allemão timber from 15 years old plantation were used. Both species are widely used in civil constructions in Costa Rica (Moya, 2004). Two species were sampled in two sawmills in Costa Rica. Dimensions of lumber in green condition were $7.5 \mathrm{~cm}$ wide by $2.5 \mathrm{~cm}$ thick; this lumber was dried in an experimental kiln and a target moisture content of $14 \%$ was established for both species (Tenorio et al., 2016; Muñoz and Moya, 2008). The PTWFs were assembled using grade 2 timber, in accordance with the Costa Rican standard for structural timber classification (INTECO, 2011).

\section{Design and construction of timber wall frames}

PTWFs were designed with measurements of $244 \mathrm{~cm}$ wide by $244 \mathrm{~cm}$ high (Figure 1a). PTWFs were designed aiming at a solid structure and fabricated with timber from logs of plantation trees, which produces timber with limited dimensions. The shape and dimensions were selected with objective to cover the PTWFs with two panels i.e. plywood, fiberboards or OSB, which presents dimension of $122 \times 244 \mathrm{~cm}$ and these can be supported in vertical and horizontal frame timber components with separations of $61 \mathrm{~cm}$. Twelve PTWFs were built per type of lumber species. Two types of fastener were used, and then six PTWFs were joined with nails and six with screws. 
Three king studs with dimensions of $5.1 \mathrm{~cm} \mathrm{x} 7.6$ $\mathrm{cm} \times 239.0 \mathrm{~cm}$ form the PTWFs: one on each lateral part of the structure and one on the central part. In addition, two common studs with dimensions of $2.5 \mathrm{~cm} \mathrm{x}$ $7.6 \mathrm{~cm} \times 239.0 \mathrm{~cm}$ were placed each between the central column and a lateral column, at the middle of the distance $(61 \mathrm{~cm})$. These five studs were joined by two horizontal pieces of $2.5 \mathrm{~cm}$ x $7.6 \mathrm{~cm}$ x $234.0 \mathrm{~cm}$ : one at the upper part (top plate) and the other at the lower part (bottom plate). Afterwards, in order to achieve a better stability of the timber wall frame, noggins of $2.5 \mathrm{~cm}$ by $7.6 \mathrm{~cm}$ were placed at every $61 \mathrm{~cm}$. Finally, eight diagonal bracing straps of $2.5 \mathrm{~cm}$ by $7.6 \mathrm{~cm}$ were placed to give the timber wall frame more rigidity (Figure 1a).

\section{Types of joint}

Five different types of joint were used for each PTWF (Figure 1a), derived from PTWF design. Joints must support lateral load and deformation in these parts so that PTWFs had excellent resistance. The joints are marked in Figure 1a and detailed below:

- Joint 1: this type is present in the corners of the timber wall frame, where the faces of the wall studs join the top and bottom plates;

- Joint 2: corresponds to the joint between each lateral king stud and the noggins;

- Joint 3: corresponds to the joint between each common stud and the noggins;

- Joint 4: is the union of the central stud with the top and bottom plates;

- Joint 5: these are the joints between diagonal bracing straps and studs.

\section{Fasteners used}

Two types of fastener were used to assemble the aforementioned PTWF, which allow a semi-rigid connection: screws and nails. Screws used were of the flat head Phillips type in two different sizes: size $7.50 \mathrm{~cm}$ by $0.49 \mathrm{~cm}$ (screw \#10) was used in joints 1 and 2; (ii) size $5.00 \mathrm{~cm}$ by $0.43 \mathrm{~cm}$ (screw \#8) was used in joints
3, 4 and 5. The nails used were of two sizes as well: (i) size $7.50 \mathrm{~cm}$ by $0.35 \mathrm{~cm}$ (nail \#10) for joints 1 and 2; (ii) size $5.10 \mathrm{~cm}$ by $0.28 \mathrm{~cm}$ (nail \#12.5) for joints 3,4 and 5. Finally, all nails and screws were inserted at approximately $2.50 \mathrm{~cm}$ from the border of each piece in order to achieve spacing close to $2.50 \mathrm{~cm}$ between each pair of fasteners. Two fasteners were used for each piece of timber that forms the joint. Each joint used the following quantity of fastener: joint 1 with 4 fasteners, 2 joint with 4 fasteners, joint 3 with 4 fasteners, joint 4 with 2 fasteners and joint 5 with 8 fasteners.

\section{Structural test for PTWFs}

Placed in a steel frame formed by columns and beams, the PTWFs were subjected to a lateral load test (Figure 1b). Each PTWF was placed at the center of the frame, one meter away from each column and, to maintain verticality, it was tied with a rope at each side. To simulate a wooden floor, a piece of lumber $(2.5 \mathrm{~cm}$ in thick and $10 \mathrm{~cm}$ in width) was anchored to the strong concrete floor by means of screws (Figure 1d, 2a). This piece of timber floor was joined to the bottom plate of the PTWFs with $75 \mathrm{~mm}$ by $3.5 \mathrm{~mm}$ (\#10) nails or 75 $\mathrm{mm}$ by $4.93 \mathrm{~mm}$ (\#10) screws, depending on the diaphragm joint type, leaving an approximate spacing of $25 \mathrm{~cm}$ between them. For application of the lateral load, the central point of the piston was placed at the height of $239 \mathrm{~cm}$, about $10 \mathrm{~cm}$ away from the superior border of the PTWFs (Figure 1c). The "Crackmeter" vibrating wire displacement transducer (VWDT) for recording of horizontal displacement was placed at the same height, whereas the one recording vertical displacement was placed at the lower corner, displacement between the king stud and the floor lumber. The lateral load and the two displacement orientations of the structure were digitally recorded during the test.

\section{Timber characterization}

The timber elements were characterized through moisture content $(M C)$ at the moment of the test, wood

a)

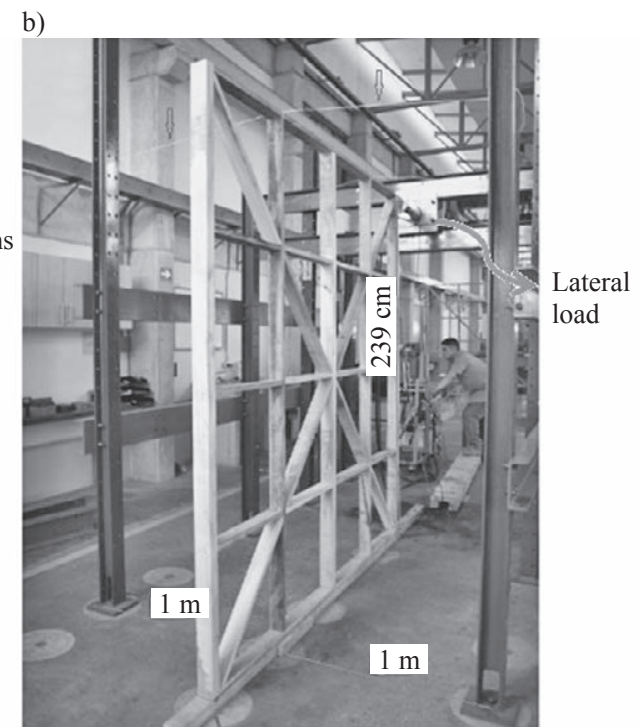

Figure 1 a) Design and type of joint of the PTWFs for H. alchorneoides and G. arborea lumbers; b) lateral test in PTWFs Slika 1. a) Dizajn i vrsta spojeva PTWF-ova izrađenih od drva H. alchorneoides i G. arborea; b) test bočnog opterećenja PTWF-ova 
density at the test $M C$ (mass volume ${ }^{-1}$ ) and specific gravity $(S G)$. Additionally, static bending and compression parallel to grain and allowable design stress were calculated. Each one of these tests was performed on 30 different samples per species. All samples were extracted from the PTWFs after the lateral load test was done. First, static bending and compression test, wood density and $M C$ were measured according to ASTM D-143 standard (ASTM, 2003a). SG was measured according to ASTM D-2395 (2003b). Allowable design stress was calculated for structural timber grade 2. Stress was derived based on the data obtained for the modulus of elasticity and modulus of rupture in flexure, while compressive stress was determined on the defect-free samples. Afterward, the procedure applied was the one indicated in ASTM D-2455 standard (ASMT, 2003c), INTECO (2011) and Moya and González (2013).

\section{Strength values of PTWFs}

For the calculation of strength values of PTWFs assembled with nails and screws, curves for load $(\mathrm{kN})$ vs displacement $(\mathrm{mm})$ were generated for vertical and horizontal directions. The values for maximum load $\left(P_{\mathrm{m}}\right)$, displacement at maximum load $\left(\Delta_{\mathrm{m}}\right)$, load at the limit of proportionality $\left(P_{\mathrm{lp}}\right)$ and displacement at the limit of proportionality $\left(\Delta_{\mathrm{lp}}\right)$ were determined in this curve. Load and displacement values in percentile 75 of the load at the proportionality limit and percentile 75 of the maximum load were also determined in this curve, for each type of PTWFs in both species and for both fastener types. To carry out the comparative analysis on the various PTWFs, the parameter of the ratio load/displacement was calculated for load at the limit of proportionality as well as for maximum load: load/ displacement relation at proportionality limit $\left(L D R_{\mathrm{lp}}\right)$ and load/displacement relation at maximum load $\left(L D R_{\mathrm{m}}\right)$, respectively. The ratio load/displacement indicates the load that must be applied for PTWFs to become displaced by $1 \mathrm{~mm}$.

\section{Calibration of model}

The purpose of a model is to represent the behavior of the PTWFs during the application of loads. Vertical and horizontal displacement data were adjusted in a digital model (Equation 1 and 2) by means of the mod- eling software SAP2000, in order to calibrate this model for the PTWFs (Figure 2b). The degree of freedom was 1 for vertical and 1 for horizontal orientation. The allowable design stresses for species used in the model are detailed in Table 1 . The model develops vertical $(\mathrm{ka})$ and horizontal rigidity $(\mathrm{kb})$ and it is derived from the general model of stiffness (force/displacement). Vertical rigidity was applied to all joints of the bottom of PTWFs (Figure 2b) and horizontal rigidity was applied to all horizontal joints on perpendicular axes of PTWFs plane (Figure 2b).

The following steps were taken to calibrate the model for both displacement orientations of the PTWFs (horizontal and vertical). The model was calibrated where the displacement transducer was located, specifically joint type 2, 3 and 4 . The joints type 1 and 5 were not taken into consideration because no displacement transducer was located:

1. A lateral load was applied to the PTWFs model in the SAP2000 software (Figure 2b), considering that the load is within the proportional range of the PTWFs, determined in the destructive test.

2. Calibration values were first obtained by using the vertical displacement value and the axial load average of the king stud - obtained when executing the model; then the horizontal displacement value and the average rotational moments in each noggin joining the king studs were obtained.

3. By means of Equation 1, initial vertical rigidity $\left(k_{a}\right)$ of type 4 joints of the PTWFs was determined, while Equation 2 was used for determining horizontal rigidity $\left(k_{b}\right)$ of type 2 and 3 joints.

$$
\begin{aligned}
& k_{a}=\frac{F}{\Delta} \\
& k_{b}=\frac{M}{\theta}
\end{aligned}
$$

Where: $k_{a}$ - vertical rigidity; $F$ - applied force; $\Delta$ - displacement produced by applied force; $k_{b}$ horizontal rigidity; $M-$ moment equivalent to force; $\theta$ - angle for moment.

4. Then, for both displacement or rotation orientations, initial rigidity was multiplied by the corresponding displacement obtained when executing the model and this product was divided by the experimental displacement in order to obtain a new

a)

b)

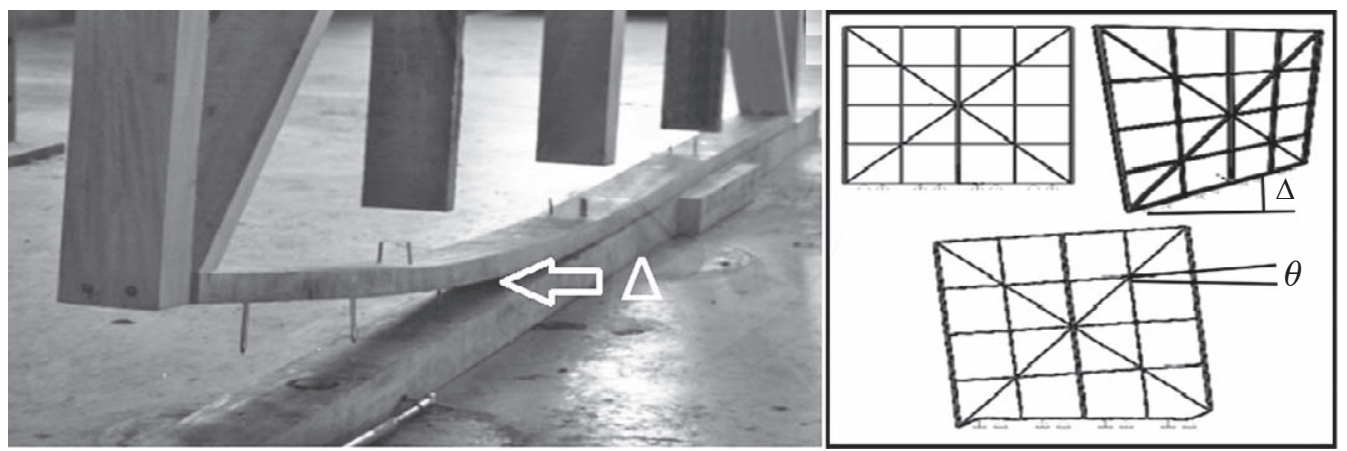

Figure 2 (a) Main failure presented in PTWFs of G. arborea and H. alchorneoides timber under lateral load: nail extraction and lifting of the king stud and (b) model in SAP2000 for PTWFs

Slika 2. (a) Glavna oštećenja koja su ustanovljena u PTWF-ovima od drva G. arborea i H. alchorneoides pri bočnom opterećenju: vađenje čavala i podizanje okvira; (b) model PTWF-ova u SAP2000 
rigidity. This procedure was applied until a $k$ (vertical and horizontal) was produced with a displacement similar to the real one - a process known as iteration.

5. Finally, the calibration percentage of the model was calculated by relationship of real horizontal displacement and horizontal displacement by model, expressed perceptually.

\section{Experimental design and statistical analysis}

A statistical $2^{2}$ factorial design was established for the PTWFs: two species (H. alchorneoides and $G$. arborea) and two fastener types (nails and screws). Of each treatment, 24 PTWFs were built $(2$ species x 2 fastener types $\mathrm{x} 6$ repetitions). Normality of the data was verified using the Shapiro-Wilks test for each of the variables measured $\left(P_{\mathrm{lp}}, \Delta_{\mathrm{lp}}, P_{\mathrm{m}}\right.$ and $\left.\Delta_{\mathrm{m}}\right)$. For variables that did not behave normally, transformation was carried out in order to comply with normality. Next, variance analysis (ANOVA) was performed considering two factors: species (H. alchorneoides and G. arborea) and the two types of ironwork in the joints (nails and screws). Finally, to determine whether significant differences existed between the treatments, a comparison of the treatments was performed by applying the Tukey test.

\section{RESULTS}

\section{REZULTATI}

\subsection{Characteristics of the lumber used}

3.1. Obilježja upotrijebljene drvne građe

Table 1 and 2 present allowable stress design and the average physical and mechanical characteristics obtained from the plantation-grown $H$. alchorneoides and $G$. arborea lumbers used in constructing the PTWFs. It shows that $H$. alchorneoides timber presented higher values for static bending and compression parallel to grain than $G$. arborea lumber, and therefore $H$. alchorneoides showed stress values higher than G. arborea. Regarding moisture content (MC), G. arborea lumber presented a slightly higher percentage than $H$. alchorneoides lumber. Meanwhile, $S G$ and density of lumber from $H$. alchorneoides are superior to those of G. arborea lumber.
Table 1 Allowable design stress for species used for construction of wooden diaphragms at the respective moisture content

Tablica 1. Dopušteno naprezanje za vrste drva koje se upotrebljavaju za izradu drvenih membrana pri odgovarajućem sadržaju vode

\begin{tabular}{|l|c|c|c|c|c|}
\hline Species / Vrsta drva & $\boldsymbol{S G}$ & $\begin{array}{c}\boldsymbol{F}_{\mathbf{b}} \\
\mathrm{MPa}\end{array}$ & $\begin{array}{c}\boldsymbol{E} \\
\mathrm{MPa}\end{array}$ & $\begin{array}{c}\boldsymbol{E}_{\min } \\
\mathrm{MPa}\end{array}$ & $\begin{array}{c}\boldsymbol{F}_{\mathbf{c}} \\
\mathrm{MPa}\end{array}$ \\
\hline Gmelina arborea & 0.42 & 6.3 & 5314 & 4517 & 3.1 \\
\hline $\begin{array}{l}\text { Hieronyma } \\
\text { alchorneoides }\end{array}$ & 0.50 & 9.3 & 6580 & 5593 & 4.6 \\
\hline
\end{tabular}

Legend: SG - specific gravity /specifična gustoća; $F_{\mathrm{b}}$ - stress in bending / naprezanje pri savijanju; $E$ - modulus of elasticity / modul elastičnosti; $E_{\min }$ - minimum modulus of elasticity / minimalni modul elastičnosti; $F_{c}$ - stress in compression parallel to grain / tlačno naprezanje paralelno s vlakancima

\subsection{Lateral load test}

\subsection{Test bočnog opterećenja}

During lateral load tests, the PTWFs showed various failures in their structure, whose incidence is shown in Figure 3. Joint 4 (the joint between the central stud and the top and bottom plates) presented the greatest percentage of failure in both species and for both fastener types used. The failure mode was by tension (Figure 3). The PTWFs of both $G$. arborea and $H$. alchorneoides lumbers using nails reached high percentages of failure in this joint, up to $100 \%$, specifically at the lower part of the structure (Figure $3 \mathrm{a}$ and 3c; Figure 2a). The PTWFs of both species that used screws, although showing this type of failure as well, recorded a lower percentage, varying from $16.6 \%$ to $66.6 \%$. Another joint that showed a high percentage of failure was Joint 1 , which reached $66.6 \%$ in PTWFs of $G$. arborea that used nails (Figure 3a). The failure mode was by shear. This type of joint failure was practically absent in PTWFs of G. arborea using screws as well as in all PTWFs of $H$. alchorneoides.

Failures in type 2 joints were present in low percentages, between 16.6 and $33.3 \%$, in all PTWFs types and failure mode was compression. In PTWFs of $H$. alchorneoides lumber with screws, no failures appeared for this joint type. Failures in joints type 3 and 5 (Figure 3a) were present in all PTWFs types but in low percentages, between 16.6 and $33.3 \%$. The failure

Table 2 Values of strength in static bending and compression parallel to grain of G. arborea and H. alchorneoides lumbers used in construction of prefabricated timber wall frames

Tablica 2. Vrijednosti čvrstoće statičkog savijanja i tlačne čvrstoće paralelno s vlakancima drva G. arborea i H. alchorneoides upotrijebljenih za izradu montažnih drvenih zidnih okvira

\begin{tabular}{|c|c|c|c|c|c|c|c|}
\hline \multirow[t]{2}{*}{$\begin{array}{l}\text { Species } \\
\text { Vrsta drva }\end{array}$} & \multicolumn{2}{|c|}{$\begin{array}{l}\text { Static bending } \\
\text { Statičko savijanje }\end{array}$} & \multicolumn{2}{|c|}{$\begin{array}{c}\text { Compression parallel } \\
\text { to grain } \\
\text { Tlačno naprezanje } \\
\text { paralelno s vlakancima }\end{array}$} & \multirow[t]{2}{*}{$\begin{array}{c}\text { Moisture } \\
\text { content } \\
\text { Sadržaj vode } \\
\%\end{array}$} & \multirow[t]{2}{*}{$\begin{array}{l}\text { Specific } \\
\text { gravity } \\
\text { Specifična } \\
\text { gustoća }\end{array}$} & \multirow[t]{2}{*}{$\begin{array}{c}\text { Density at reported } \boldsymbol{M C} \\
\text { Gustoća pri izmjerenom } \\
\text { sadržaju vode } \\
\mathrm{kg} / \mathrm{m}^{3}\end{array}$} \\
\hline & $M O E, \mathrm{GPa}$ & $M O R, \mathrm{MPa}$ & $M O E, \mathrm{MPa}$ & $M O R, \mathrm{MPa}$ & & & \\
\hline $\begin{array}{l}\text { Gmelina } \\
\text { arborea }\end{array}$ & $6.4^{\mathrm{A}}(21.7)$ & $\begin{array}{l}44.9^{\mathrm{A}} \\
(25.3)\end{array}$ & $\begin{array}{l}590^{\mathrm{A}} \mathrm{b} \\
(15.2)\end{array}$ & $\begin{array}{l}24.4^{\mathrm{A}} \\
(14.9)\end{array}$ & $14.5^{\mathrm{A}}(21.9)$ & $0.42^{\mathrm{A}}(12.11)$ & $\begin{array}{c}520^{\mathrm{A}} \\
(11.82)\end{array}$ \\
\hline $\begin{array}{l}\text { Hieronyma } \\
\text { alchorneoides }\end{array}$ & $7.9^{\mathrm{B}}(13.9)$ & $\begin{array}{l}66.8^{\mathrm{B}} \\
(15.9)\end{array}$ & $1079^{\mathrm{B}}(9.9)$ & $\begin{array}{c}36.4^{\mathrm{B}} \\
(10.1)\end{array}$ & $\begin{array}{l}13.8^{\mathrm{A}} \\
(6.0)\end{array}$ & $0.50^{\mathrm{B}}(8.87)$ & $\begin{array}{c}590^{\mathrm{B}} \\
(9.20)\end{array}$ \\
\hline
\end{tabular}

Legend: $M O E$ - modulus of elasticity / modul elastičnosti; $M O R$ - modulus of rupture / modul loma. Values between parentheses correspond to the coefficient of variation for the given variable. Different characters indicate significant differences at $p=0.05$. / Vrijednosti $u$ zagradama odgovaraju koeficijentima varijacije za dane varijable. Različita slova pokazuju značajne razlike uz $p=0,05$. 
a)

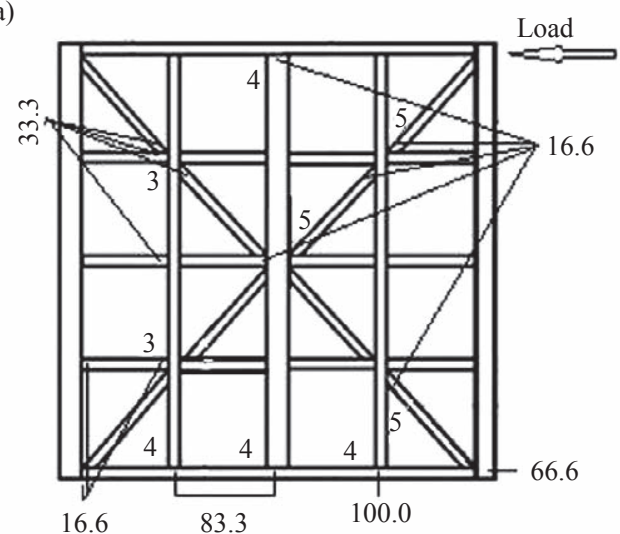

c)

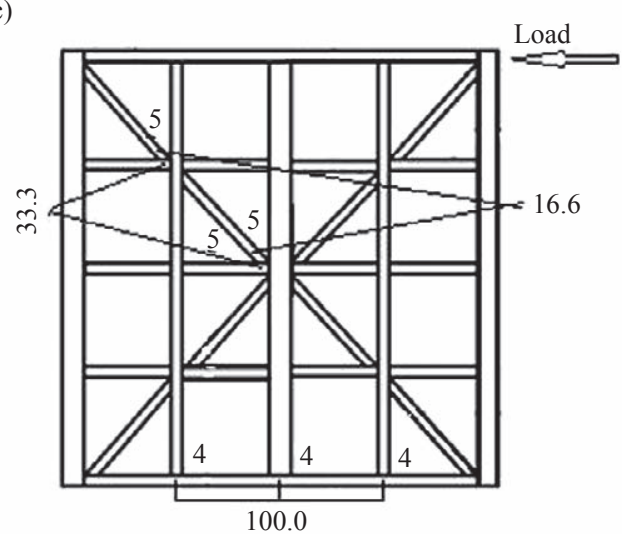

b)

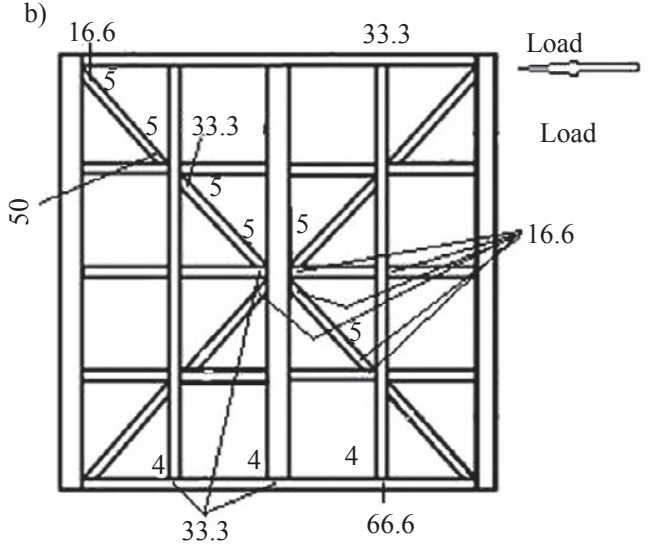

d)

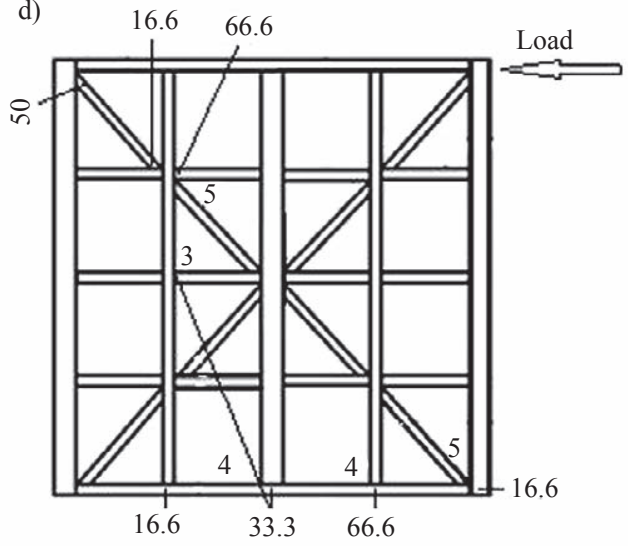

Figure 3 Percentage of failures present in various PTWF joints after lateral load test. PTWFs made of: a) G. arborea timber and nails; b) G. arborea timber and screws; c) H. alchorneoides timber and nails; and d) H. alchorneoides timber and screws Slika 3. Postotak oštećenja uočenih u različitim spojevima PTWF-a nakon testa bočnog opterećenja. PTWF-ovi izrađeni od: a) drva G. arborea i čavala; b) drva G. arborea i vijaka; c) drva H. alchorneoides i čavala; i d) drva H. alchorneoides i vijaka.

mode was compression in joint type 3 and tension in joint type 4. Likewise, it is important to note that more failures occurred in PTWFs made of $G$. arborea lumber (Figure 3a-b) than in PTWFs made of H. alchorneoides lumber (Figure 3c-d).

Table 3 shows the strength values in horizontal and vertical orientations in relation to the lateral load applied on the PTWFs (average load at proportionality limit $\left(P_{\mathrm{lp}}\right)$ and displacement at proportionality limit $\left(\Delta_{\mathrm{lp}}\right)$ in percentile 75; average $P_{\mathrm{m}}$ and displacement at maximum load $\left(\Delta_{\mathrm{m}}\right)$ in percentile 75$)$. It can be observed that, in the horizontal orientation, the $P_{1 \mathrm{p}}$ of the PTWFs varies from 1.6 to $2.9 \mathrm{kN}$ and the $P_{\mathrm{m}}$ from 1.9 to $3.7 \mathrm{kN}$. Meanwhile, displacement $(\Delta)$ in these points varies from 23.2 to $38.4 \mathrm{~mm}$ and from 30.2 to 55.6 $\mathrm{mm}$, respectively. In the vertical orientation, $P_{\mathrm{lp}}$ varies from 1.7 to $2.9 \mathrm{kN}$ and the $P_{\mathrm{m}}$ from 1.9 to $3.8 \mathrm{kN}$, while the $\Delta_{\mathrm{lp}}$ varies from 4.8 to $10.8 \mathrm{~mm}$ and the $\Delta_{\mathrm{m}}$ from 8.2 to $27.3 \mathrm{~mm}$.

It is observed that, for both vertical and horizontal orientations, PTWFs using G. arborea lumber and nails presented the statistically lowest value in $P_{\mathrm{lp}}$ and $P_{\mathrm{m}}$. For both orientations, $P_{\mathrm{lp}}$ was statistically similar in PTWFs made of $G$. arborea lumber with the use of either screws or nails, as well as in H. alchorneoides PTWFs using nails, whereas it was statistically higher in PTWFs made of $H$. alchorneoides lumber using screws. The highest $P_{\mathrm{m}}$ was found in the PTWFs made of either lumber species using screws, while PTWFs using $G$. arborea lumber with nails showed a significantly lower $P_{\mathrm{m}}$ in comparison to PTWFs using G. arborea lumber and screws and PTWFs using $H$. alchorneoides lumber and either nails or screws.

It was found for the horizontal and vertical $\Delta_{\mathrm{lp}}$ that PTWFs made of $H$. alchorneoides showed a greater $L D R_{\mathrm{lp}}$ than $G$. arborea PTWFs (Table 3), with the exception of the vertical displacement in the H. alchorneoides PTWFs using nails, where the $L D R_{\mathrm{lp}}$ value shown was lower than that of G. arborea PTWFs using screws (Table 3). For both orientations, at the moment of failure, the greatest $L D R_{\mathrm{m}}$ was recorded in $H$. alchorneoides PTWFs using screws; the lowest $L D R_{\mathrm{m}}$ on the horizontal direction was shown in $G$. arborea PTWFs and, for the vertical direction, the lowest $L D R_{\mathrm{m}}$ was recorded in $H$. alchorneoides PTWFs using nails.

Another important aspect is that the average values for $P_{\mathrm{lp}}$ and $P_{\mathrm{m}}$ are similar for both orientations in both species and both fastener types, yet a difference can be observed in the displacement values, which are higher in the horizontal orientation (Table 3).

Figure 4 presents the relation between load and displacement in the horizontal and vertical orientations for the various PTWFs of both types of lumber and fasteners. It has been observed that in PTWFs from either lumber species using screws the values of load for a given displacement are superior to those of PTWFs using nails for the same displacement. In the same way, it has been observed that the loads obtained for a given 
Table 3 Strength values in horizontal and vertical displacement under lateral load obtained for PTWFs made of G. arborea and $H$. alchorneoides lumbers

Tablica 3. Vrijednosti čvrstoće u horizontalnome i vertikalnom smjeru pri bočnom opterećenju PTWF-ova izrađenih od drva G. arborea i H. alchorneoides

\begin{tabular}{|c|c|c|c|c|c|c|c|}
\hline \multirow[b]{2}{*}{$\begin{array}{l}\text { Species } \\
\text { Vrsta drva }\end{array}$} & \multirow{2}{*}{$\begin{array}{c}\text { Type of fastener } \\
\text { Vrsta vezivnih } \\
\text { elemenata }\end{array}$} & \multicolumn{6}{|c|}{ Horizontal / Horizontalno } \\
\hline & & $\begin{array}{l}P_{\mathrm{lp}} \\
\mathrm{kN}\end{array}$ & $\begin{array}{l}\Delta_{\mathrm{lp}} \\
\mathrm{mm}\end{array}$ & $\begin{array}{l}L D R_{\mathrm{lp}} \\
\mathrm{kN} / \mathrm{mm}\end{array}$ & $\begin{array}{l}P_{\mathrm{m}} \\
\mathrm{kN}\end{array}$ & $\begin{array}{c}\Delta_{\mathrm{m}} \\
\mathrm{mm}\end{array}$ & $\begin{array}{l}L D R_{\mathrm{m}} \\
\mathrm{kN} / \mathrm{mm}\end{array}$ \\
\hline \multirow[t]{2}{*}{ Gmelina arborea } & Nail / čavli & $1.6^{\mathrm{A}}(13.2)$ & $24.9(21.6)$ & $0.06^{\mathrm{A}}$ & $1.9^{\mathrm{A}}(12.8)$ & $33.8(17.4)$ & $0.06^{\mathrm{A}}$ \\
\hline & Screw / vijci & $2.8^{\mathrm{BC}}(10.3)$ & $38.4(23.0)$ & $0.07^{\mathrm{AB}}$ & $3.6^{\mathrm{BC}}(11.9)$ & $55.6(20.3)$ & $0.06^{\mathrm{AB}}$ \\
\hline \multirow{3}{*}{$\begin{array}{l}\text { Hieronyma } \\
\text { alchorneoides }\end{array}$} & Nail / čavli & $2.2^{\mathrm{B}}(22.0)$ & $18.1(15.1)$ & $0.12^{\mathrm{BC}}$ & $2.6^{\mathrm{AB}}(16.3)$ & $30.2(15.3)$ & $0.09^{\mathrm{AB}}$ \\
\hline & Screw / vijci & $2.9^{\mathrm{C}}(16.5)$ & $23.2(12.9)$ & $0.13^{\mathrm{C}}$ & $3.7^{\mathrm{C}}(12.2)$ & $30.6(14.3)$ & $0.12^{\mathrm{B}}$ \\
\hline & & \multicolumn{6}{|c|}{ Vertical / Vertikalno } \\
\hline \multirow[t]{2}{*}{ Gmelina arborea } & Nanl/ cavll & $1.7^{\mathrm{A}}(7.7)$ & $9.4(7.2)$ & $0.18^{\mathrm{A}}$ & $1.9^{\mathrm{A}}(12.8)$ & $13.0(21.6)$ & $0.15^{\mathrm{AB}}$ \\
\hline & Screw / vijci & $2.8^{\mathrm{BC}}(11.5)$ & $7.0(32.7)$ & $0.40^{\mathrm{AB}}$ & $3.5^{\mathrm{BC}}(14.5)$ & $8.2(6.3)$ & $0.43^{\mathrm{BC}}$ \\
\hline \multirow{2}{*}{$\begin{array}{l}\text { Hieronyma } \\
\text { alchorneoides }\end{array}$} & Nail / čavli & $2.2^{\mathrm{B}}(22.1)$ & $10.8(37.0)$ & $0.20^{\mathrm{AB}}$ & $2.6^{\mathrm{AB}}(12.1)$ & $27.3(18.6)$ & $0.10^{\mathrm{A}}$ \\
\hline & Screw / vijci & $2.9^{\mathrm{C}}(14.0)$ & $4.8(17.9)$ & $0.60^{\mathrm{B}}$ & $3.8^{\mathrm{C}}(3.9)$ & $8.2(35.0)$ & $0.46^{\mathrm{C}}$ \\
\hline
\end{tabular}

$P_{\mathrm{lp}}$ - load at limit of proportionality / opteréenje na granici proporcionalnosti; $\Delta_{\mathrm{lp}}$ - displacement at limit of proportionality / pomak na gran-

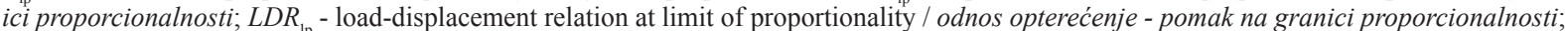
$P_{\mathrm{m}}$ - maximum load / maksimalno opteré́enje; $\Delta_{\mathrm{m}}$ - displacement at maximum load / pomak pri maksimalnom opterećenju; LDR $R_{\mathrm{m}}$ - load-displacement relation at maximum load / odnos opterećenje - pomak pri maksimalnom opteré́enju. Values between parentheses correspond to the coefficient of variation for the given variable. / Vrijednosti u zagradama odgovaraju koeficijentima varijacije za dane varijable. Different characters indicate significant differences at $p=0.05$. / Različita slova pokazuju značajne razlike uz $p=0,05$.

displacement in the PTWFs made of H. alchorneoides lumber are greater than those obtained for the PTWFs made of $G$. arborea lumber. Another important aspect to note from the load-displacement relation is that, after the maximum load point is reached, irregularities appear in the load-displacement values of the PTWFs - specifically, fluctuations in these values take place as the structure continues to become displaced.

\section{Calibration}

For modeling the PTWFs, the values of rigidity $(k)$ and displacement (shown in Table 4) for the joints in the vertical and horizontal orientations were determined by means of the SAP2000 software. The recorded values of $k$ for PTWFs using nails were $0.035 \mathrm{kN} /$ $\mathrm{mm}$ for $G$. arborea lumber and $0.053 \mathrm{kN} / \mathrm{mm}$ for $H$. alchorneoides, whereas PTWFs made of either species using screws showed a superior rigidity, 255 and 485 $\mathrm{kN} / \mathrm{mm}$, respectively. Again, the computational model shows that the highest values are present in PTWFs made using $H$. alchorneoides lumber.

In evaluating the computational model with the real values, it was found that the highest calibration percentage was achieved in the vertical orientation in PTWFs made using nails in both species. Meanwhile,
PTWFs using screws showed calibration percentages of 58.0 and $43.5 \%$ (Table 4 ). No uniform calibration percentage appeared in the horizontal orientation: PTWFs made of $G$. arborea lumber using nails achieved $100 \%$, while PTWFs using H. alchorneoides lumber and nails presented a percentage lower than $62.9 \%$. Finally, the greatest calibration percentage average was obtained in the PTWFs made of G. arborea lumber using nails, while the lowest calibration percentage appeared in H. alchorneoides PTWFs using screws.

\section{DISCUSSION \\ 4. RASPRAVA}

\subsection{Lateral load test}

4.1. Test bočnog opterećenja

As was to be expected, the main faults in PTWFs during lateral load tests were due to the failure of joints, which is caused by the bending of metal pieces acting as transmitters of the load, becoming the most critical regions (Prevatt et al., 2014). One aspect that weakens the joints is that elements placed with their axis parallel to the wood fibers offer low or null resistance to extraction, either directly or by action of lateral loads (Prevatt

Table 4 Computed and real values of rigidity and displacement (vertical and horizontal) obtained for PTWFs made of $G$. arborea and H. alchorneoides lumbers and calibration percentages of computational model

Tablica 4. Izračunane i stvarne vrijednosti krutosti i pomaka (vertikalno i horizontalno) dobivene za PTWF-ove od drva G. arborea i H. alchorneoides te postotak kalibracije računalnog modela

\begin{tabular}{|c|c|c|c|c|c|c|c|c|c|}
\hline $\begin{array}{l}\text { Type of PTWFs } \\
\text { Vrsta PTWF-ova }\end{array}$ & $\begin{array}{c}\boldsymbol{k}_{\mathrm{a}} \\
\mathrm{kN} / \mathrm{mm}\end{array}$ & $\begin{array}{l}\Delta_{\mathrm{vr}} \\
\mathrm{mm}\end{array}$ & $\begin{array}{c}\Delta_{\mathrm{v}} \\
\mathrm{mm}\end{array}$ & $\%_{c}$ & $\begin{array}{c}\boldsymbol{k}_{\mathbf{b}} \\
\mathrm{kN} / \mathrm{mm}\end{array}$ & $\begin{array}{c}\Delta_{\mathrm{hr}} \\
\mathrm{mm}\end{array}$ & $\begin{array}{c}\Delta_{\mathbf{h}} \\
\mathrm{mm}\end{array}$ & $\%_{c}$ & $\begin{array}{c}\text { Average } \\
\text { Prosječno } \\
\%_{\mathrm{c}}\end{array}$ \\
\hline G. arborea-nail / čavli & 0.035 & 5 & 6.3 & 80 & 756 & 13 & 13 & 100 & 89.9 \\
\hline G. arborea-screw / vijci & 255.3 & 2 & 3.1 & 58 & 6676 & 9.7 & 8.6 & 88 & 73.2 \\
\hline H. alchorneoides - nail / čavli & 0.053 & 5 & 3.8 & 78 & 4104 & 5.1 & 8.1 & 63 & 70.2 \\
\hline H. alchorneoides -screw / vijci & 485.2 & 1 & 3.1 & 44 & 4836 & 6.2 & 6.5 & 95 & 69.4 \\
\hline
\end{tabular}

$k_{\mathrm{a}}$ - vertical rigidity for calibration / vertikalna krutost za kalibraciju; $\Delta_{\mathrm{vr}}$ - real vertical displacement / stvarni vertikalni pomak; $\Delta_{\mathrm{vm}}-\mathrm{vertical}$ displacement by model / vertikalni pomak prema modelu; $\%_{\mathrm{c}}$ - calibration percentage / postotak kalibracije; $k_{\mathrm{b}}$ - horizontal rigidity for horizontal calibration / horizontalna krutost za horizontalnu kalibraciju; $\Delta_{\mathrm{hr}}$ - real horizontal displacement / stvarni horizontalni pomak; $\Delta_{\mathrm{hm}}$ - horizontal displacement by model / horizontalni pomak prema modelu 
et al., 2014). Therefore, PTWFs joints where nails and screws were used in this orientation (joints 3 and 4) failed more frequently. In order to improve the structural performance of these faulty spots, it is necessary to reinforce the joints by using elements with better structural performance, for example dented plates, gluing, steel plates, among others (Fueyo et al., 2011). Another factor that contributes in improving the performance of joints and, therefore, the behavior of the PTWFs, is the covering of the walls (Demirkir et al., 2013), especially using materials with a better performance under structural loads (Bongers et al., 2013; Chen et al., 2016).

The PTWFs made of $G$. arborea lumber using nails showed lower strength under lateral load (Table 3) and greater displacement for the same load (Figure 4) in relation to PTWFs made of $H$. alchorneoides lumber using nails. This occurs because the former is considered as lumber of a medium SG (Moya, 2004), inferior to that of $H$. alchorneoides lumber (Table 1). Therefore, timbers of low SG have greater ductility (Demirkir et al., 2013), thus causing greater deformation. On the contrary, PTWFs made of $H$. alchorneoides timber showed greater strength and a better behavior under lateral loads because of its superior SG, which provides greater hardness and resistance to extraction of the nails (Celebi and Kilic, 2007). In general, it is considered that strength of the joints increases as density increases (Demirkir et al., 2013).

However, it is fair to note that, although the SG of $H$. alchorneoides timber is $16 \%$ higher than that of G. arborea timber (Table 2), the differences in strength and displacement values are not as great. In fact, in PTWFs made of $G$. arborea lumber and using screws and PTWFs made of $H$. alchorneoides lumber and using nails, no significant differences were shown in parameters at the limit of proportionality. Another result that confirms little differences between both species is the $P_{\mathrm{m}}$ in PTWFs made of either species using nails, as no significant differences appeared in this value (Table 3 ).

According to the abovementioned behavior, it is inferred that the strength of the PTWFs model is largely limited by the type of the fastener used (nail or screw) and not by the type of timber used. However, in order to determine the real differences between species, joint structures must be controlled and designed so as to withstand forces and collapse due to the lumber type and not due to the joint type. Nonetheless, the objective of this study was to develop a design mainly oriented toward the failure by the type of joint.

a)

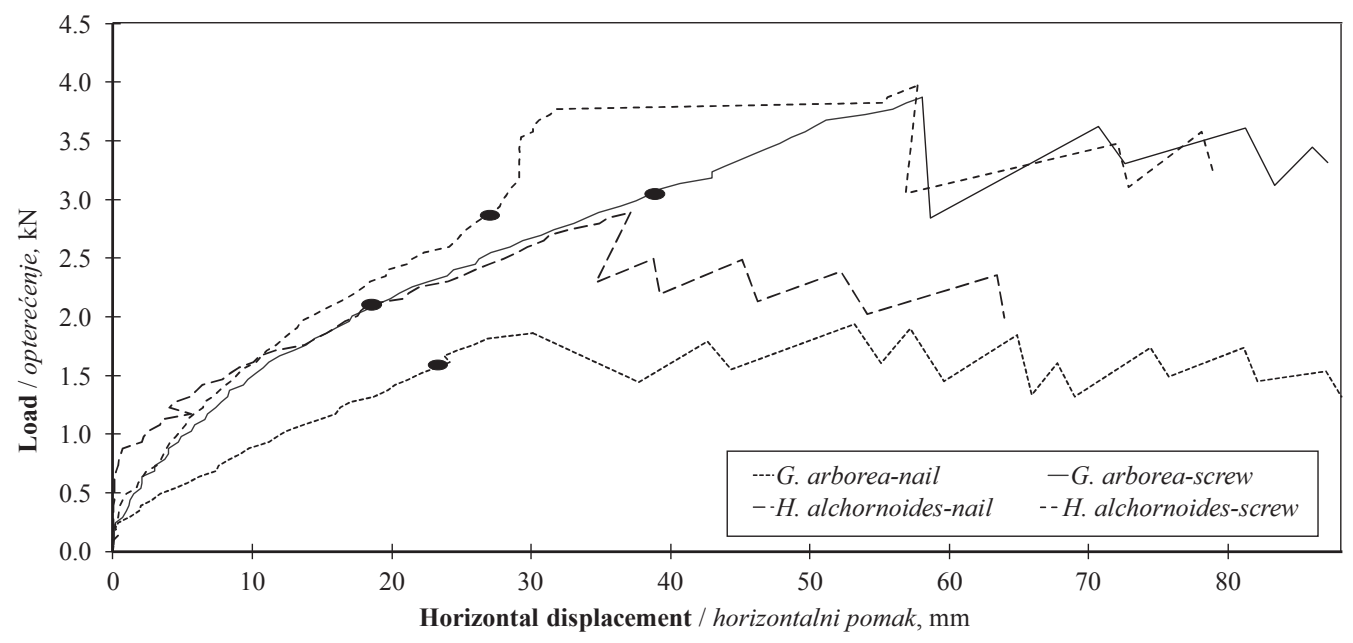

b)

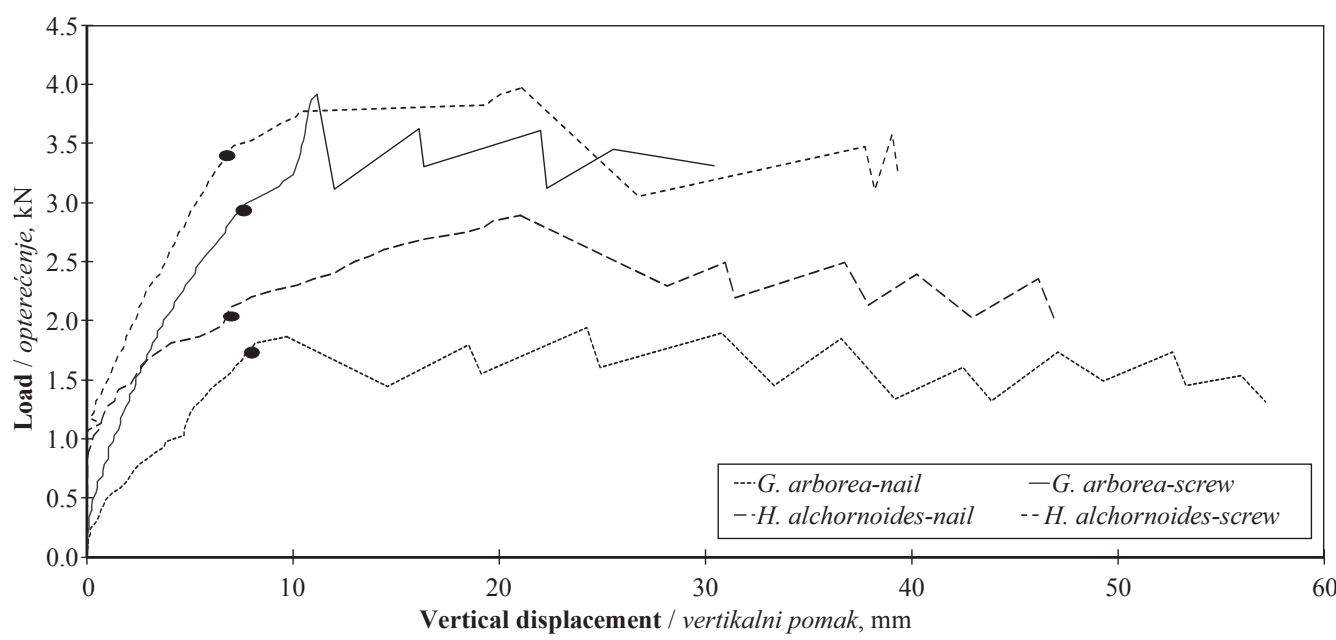

Figure 4 Behavior of load as a function of displacement in horizontal and vertical orientations for PTWFs made of G. arborea and $H$. alchorneoides lumbers: a) load-displacement in horizontal orientation; b) load-displacement in vertical orientation

Slika 4. Ponašanje opterećenja kao funkcije pomaka u horizontalnome i vertikalnom smjeru za PTWF-ove od drva G. arborea i H. alchorneoides: a) odnos opterećenja i pomaka u horizontalnom smjeru; b) odnos opterećenja i pomaka u vertikalnom smjeru 
The greater resistance to loads and the lesser displacements shown in PTWFs using screws, mainly in the vertical direction, are due to the threaded area of the screw, which allows for more adherence to the wood fibers and thus more resistance to extraction by various forces (Demirkir et al., 2013; Gattesco and Boem, 2015). Nails, lacking this quality, are extracted more easily under lower loads, generating greater displacement of the structure (Demirkir et al., 2013). Although screws performed better than nails as expected, the results are interesting since they quantify the difference.

Another aspect observed from the load-displacement curves (Figure 4) is represented by the sudden drops of the load after overcoming maximum resistance of the PTWFs, manifested at the moment of total extraction or failure of the joint elements. Gattesco and Boem (2015) explain that this is due to exceeding the capacity of the joint elements to withstand deformation and, consequently, these lose their ability to transmit the load. These sudden drops in load were also present in a study by Sartori and Tomasi (2013) on structures using metal fasteners and coated walls. However, this irregularity is not a severe problem, as structures with semirigid joints allow for irregular drops of the load, wherein the structure suffers partial damage and the joints are able to dissipate energy (Gattesco and Boem, 2015). Thus, a process of redistribution of loads begins after failure of a joint, which allows the wall not to collapse (Branco and Descamps, 2015) and this enables the diaphragms to support load again, until failure of the joints takes place anew and another sudden drop of load follows (Figure 4).

\subsection{Calibration of the model}

\subsection{Kalibracija modela}

In order to obtain reliable predictions from the model in performing a comprehensive analysis of the structure, it is fundamental to calibrate the PTWFs constructed (Chui et al., 2016). In the present study, the calibration percentage obtained for PTWFs made of either G. arborea or H. alchorneoides timbers was 81.5 $\%$ and $69.8 \%$, respectively, which is low in comparison to other type of materials (Rodríguez et al., 2011). The moderately low coefficients in the PTWFs model of this study, of less than $82 \%$, may be explained by the nature of the material used for these structures (lumber), which presents greater variability than other material such as steel, concrete or aluminum (Tuk, 2010). Moreover, another aspect causing the low calibration of the PTWFs is that joints behave as partially rigid elements, which renders calibration of the model more complex. It is advisable to determine rigidity in each joint in order to achieve an adequate degree of freedom in these spots. Another situation that contributes to low correlation is the failure caused by lifting of bottom plate from the floor lumber (Figure 2a). By improving the joint at this point, probably by using large screws instead of nails, the resistance at this point could improve the lateral resistance.

Diaphragms built with nails showed lesser axial rigidity than those built with screws (Table 4), which coincides with the lower load-displacement rate in the vertical orientation (Table 4). This behavior may be considered logical, as less rigid joints would allow greater displacement at lower loads - when nails are used, for example. Rigidity in bending presented higher values in PTWFs with $H$. alchorneoides lumber using screws and nails, a behavior made possible by a combination of factors, among which a greater torque momentum can be noted as a consequence of a more rigid joint (Prevatt et al., 2014).

Finally, the lowest calibration percentage was shown in PTWFs made of $H$. alchorneoides timber using screws in the vertical orientation, as well as those made of the same timber using nails in the horizontal direction (Table 4). This low calibration level is the product of lower loads, within the range of 0 to $1 \mathrm{kN}$ (Figure 4), as it was not possible to adjust the modeling software to such low values.

\section{CONCLUSIONS \\ 5. ZAKLJUČAK}

A model for the calibration of PTWFs made of Gmelina arborea and Hieronyma alchorneoides lumber using two types of fastener (nails and screws) was developed. Differences between these two types of lumber were determined. It was possible to calibrate the models by means of the modeling software, wherein a greater calibration percentage was obtained for $G$. arborea PTWFs using nails (89.9\%), while the lowest calibration percentage $(69.4 \%)$ was obtained for $H$. alchorneoides PTWFs built using screws.

PTWFs made of $G$. arborea lumber presented lower load (from 1.6 to $2.9 \mathrm{kN}$ ) and displacement values at the limit of proportionality in both vertical and horizontal orientations (from 18.1 to $38.4 \mathrm{~mm}$ ). G. arborea PTWFs showed a greater $P_{\mathrm{m}}$ in the horizontal direction $(3.6 \mathrm{kN})$, yet there are no clear differences between these two types of timber in the vertical direction. Based on these results, PTWFs made of $\mathrm{H}$. alchorneoides timber using screws showed the highest values of the properties measured (from 2.2 to $3.7 \mathrm{kN}$ ).

The results obtained for PTWFs made of $G$. arborea and Hieronyma alchorneoides timber contribute to the knowledge of the structural properties of wall frames made of tropical timber species for framing constructions.

\section{Acknowledgements - Zahvala}

The authors are grateful for the support of the Vicerrectoría de Investigación y Extensión of the Instituto Tecnológico de Costa Rica, as well as Aserraderos S\&Q S.A. and Ecomaderas S.A., who contributed the materials for the prefabricated wall frames.

\section{REFERENCES}

\section{LITERATURA}

1. Branco, J. M.; Descamps, T., 2015: Analysis and strengthening of carpentry joints. Construction and Building Materials, 97: 34-47.

http://doi.org/10.1016/j.conbuildmat.2015.05.089. 
2. Bongers, F.; Alexander, J.; Marcroft, J.; Crawford, D.; Hairstans, R., 2013: Structural design with Accoya wood. International Wood Products Journal, 4 (3): 172-176. http://doi.org/10.1179/2042645313Y.0000000041.

3. Celebi, G.; Kilic, M., 2007: Nail and screw withdrawal strength of laminated veneer lumber made up hardwood and softwood layers. Construction and Building Materials, 21 (4): 894-900. http://doi.org/10.1016/j.conbuildmat.2005.12.015.

4. Chen, Z.; Chui, Y. H.; Doudak, G.; Nott, A., 2016: Contribution of type-x gypsum wall board to the racking performance of light-frame wood shear walls. Structural Engineering Journals, 142 (5): 04016008. http://doi.org/10.1061/(ASCE)ST.1943-541X.0001468.

5. Chui, Y. H.; Ni, C.; Jiang, L., 1998: Finite-element model for nailed wood joints under reversed cyclic load. Structural Engineering Journals, 124 (1): 96-103. http://doi. org/10.1061/(ASCE)0733-9445(1998)124:1(96)\#sthash. R5CCp6Jo.dpuf.

6. Demirkir, C.; Colakoglu, G.; Karacabeyli, E., 2013: Effect of manufacturing factors on technological properties of plywood from northern turkey and suitability of panels for use in shear walls. Structural Engineering Journals, 139 (12): 04013002. http://doi.org/10.1061/(ASCE) ST.1943-541X.0000777\#sthash.Ynj8KUqc.dpuf.

7. Fueyo, J. G.; Domínguez, M.; Cabezas, J. A., 2011: Performance of dowel-type joints of the glued in rod type using finite elements (In Spanish). Informes Tecnológicos, 22 (4): 117-128.

8. Gattesco, N.; Boem, I., 2015. Seismic performances and behavior factor of post-and-beam timber buildings braced with nailed shear walls. Engineering Structures, 100: 674685. http://doi.org/10.1016/j.engstruct.2015.06.057.

9. Moya, R.; González, G., 2013: Allowable stress design by structural grade for nine plantation woods of Costa Rica (in Spanish). Revista Forestal Mesoamericana, 11 (26): 1-11. http://doi.org/10.18845/rfmk.v11i26.1589.

10. Moya, R.; Salas, C.; Berrocal, A.; Valverde, J. C., 2015: Evaluation of chemical compositions, air-dry preservation and workability of eight fast-growing plantation species in Costa Rica. Maderas y Bosques, 21 (especial): 31-47.

11. Moya, R.; Tenorio, C.; Carranza, M.; Camacho, D.; Quesada-Pineda, H., 2013: Structural performance of I-beam fabricated of Gmelina arborea from fast growing trees. Journal of Tropical Forest Science, 25: 206-212.

12. Moya, R., 2004: Wood of Gmelina arborea in Costa Rica. New Forests, 28 (2-3): 299-317. http://doi.org/10.1023/B:NEFO.0000040957.83398.e3.

13. Muñoz, F.; Moya, R., 2008: Moisture content variability in kiln-dried Gmelina arborea wood: Effect of radial position and anatomical features. Journal of Wood Science, 54 (4): 318-322. http://doi.org/10.1007/s10086-0080954-8.

14. Prevatt, D. O.; Shreyans, A. K.; Gurley, K. R., 2014: In situ nail withdrawal strengths in wood roof structures. Structural Engineering Journal, 140 (5): 04014008. http://doi.org/10.1061/(ASCE)ST.1943541X.0000990\# sthash.ujG2E2Ei.dpuf.

15. Rathod, S., 2015: Sustainable building: An review. Rathod. International Journal of Advances in Engineering and Technology, 6 (1): 11-13.

16. Rodríguez, W.; Muñoz, E.; Núñez, F., 2011. Optimization applied to the calibration and validation of finite element models of bridges (in Spanish). Revista de Ingeniería, 17 (1): 43-59.

17. Sawata, K.; Shigemoto, Y.; Hirai, T.; Koizumi, A.; Sasaki, Y., 2013: Shear resistance and failure modes of nailed joints loaded perpendicular to the grain. Journal of Wood Science, 59: 255-261. http://doi.org/10.1007/s10086-012-1317-z.

18. Serrano, R.; Moya, R., 2011. Process, use and timber market in Costa Rica: Historical aspects and critical analysis (in Spanish). Revista Forestal Mesoamericana, 8 (21): 1-12.

19. Sheikh, S.; Ahmad, Y., 2015: Flexural strengthening of structural timber in the $21^{\text {st }}$ century: A state of the art review. Applied Mechanics and Materials, 735: 128-140. http://doi.org/10.4028/www.scientific.net/AMM.735.128.

20. Sartori, T.; Tomasi, R., 2013: Experimental investigation on sheathing-to-framing connections in wood shear walls. Engineering Structures, 56: 2197-2205. http://doi.org/10.1016/j.engstruct.2013.08.039.

21. Tenorio, C.; Moya, R.; Salas, C.; Berrocal, A., 2016: Evaluation of wood properties from six native species of forest plantations in Costa Rica. Revista Bosques, 33 (2): 78-87. http://doi.org/10.4067/S0717-92002016000100008.

22. Tenorio, C.; Moya, R.; Muñoz, F., 2011: A comparative study on physical and mechanical properties of LVL and plywood panels made of wood from fast growing Gmelina arborea trees. Journal of Wood Science, 57: 134139. http://doi.org/10.1007/s10086-010-1149-7.

23. Tenorio, C.; Moya, R.; Camacho, D., 2012: Physical and mechanical properties of plywood panels manufactures with tropical plantation species for structural use. Cerne, 18 (2): 317-325. http://doi.org/10.1590/S0104-77602012000200017.

24. Tenorio, C.; Salas, C.; Moya, R., 2016: Kiln drying behavior utilizing drying rate of lumber from six fastgrowth plantation species in Costa Rica. Drying Technology, 34: 443-453. http://doi.org/10.1080/07373937.2015.1060493.

25. Tuk, J., 2010: Design and construction (in Spanish). Colegio De Ingenieros y Arquitectos. San José, Costa Rica.

26. Zheng, W.; Lu, W.; Liu, W.; Wang, L.; Ling, Z., 2015: Experimental investigation of laterally loaded doubleshear-nail connections used in mid plywood shear walls. Construction and Building Materials. 101: 761-771. http://doi.org/10.1016/j.conbuildmat.2015.10.100.

27. *** 2003: ASTM (American Society for Testing and Materials. US). D 143-94. Standard test methods for small clear specimens of timber. In Annual Book of ASTM Standards. Philadelphia. US. ASTM. Vol. 04.10.

28. *** 2003: ASTM (American Society for Testing and Materials. US) D 2395-02 Standard test methods for specific gravity of wood and wood-base materials. In Annual Book of ASTM Standards. Philadelphia. US. ASTM. Vol. 04.10.

29. *** 2003: ASTM (American Society for Testing and Materials. US). D 2555-02 Standard test methods for establishing clear wood strength values. In Annual Book of ASTM Standards. Philadelphia. US. ASTM. Vol. 04.10.

30. *** 2011: INTECO (Instituto de Normas Técnicas de Costa Rica). 2011. Structural Classification structural wood for lumber grades by visual assessment (in Spanish). San José. Costa Rica.

\section{Corresponding address:}

\section{ROGER MOYA, Ph.D.}

Instituto Tecnológico de Costa Rica

Escuela de Ingeniería Forestal

Apartado 159-7050

Cartago, COSTA RICA

e-mail: rmoya@itcr.ac.cr 